\title{
The black scabbardfish (Aphanopus carbo Lowe, 1839) fisheries from the Portuguese mainland and Madeira Island
}

\author{
PEDRO BORDALO-MACHADO ${ }^{1}$, ANA CLÁUDIA FERNANDES ${ }^{1}$, \\ IVONE FIGUEIREDO $^{1}$, OLGA MOURA ${ }^{1}$, SARA REIS ${ }^{2}$, GRAÇA PESTANA ${ }^{1}$ \\ and LEONEL SERRANO GORDO ${ }^{3}$
}

\author{
${ }^{1}$ INRB / L-IPIMAR, Avenida de Brasília, 1449-006 Lisboa, Portugal. E-mail: bmachado@ipimar.pt \\ 2 Direcção de Serviços de Investigação das Pescas, Estrada da Pontinha, 9004-562 Funchal, Portugal. \\ ${ }^{3}$ Departamento de Biologia Animal and Centro de Oceanografia, Faculdade de Ciências da Universidade de Lisboa, \\ Bloco C2, Campo Grande, 1749-016 Lisboa, Portugal.
}

SUMMARY: For several decades, the black scabbardfish (Aphanopus carbo, Lowe 1839) has been a valuable resource for fishing communities in Madeira and more recently for those in mainland Portugal. The evaluation of the species' exploitation status was conducted only in the late 20th century and separated for the two areas of the Portuguese Exclusive Economic Zone (EEZ). Nowadays, species stock assessment studies are usually conducted in the framework of scientific working groups from regional fisheries organizations: ICES analyses data from the fishery operating in continental waters, whereas CECAF deals with the data pertaining to the Madeiran fishery. This paper presents the first attempt to combine the information available from the two longline fisheries targeting black scabbardfish in Portuguese waters in one single analysis. A description of the two fleets' technical characteristics was conducted and a unique model was developed for the standardization of the fishing effort aimed at the species in the Portuguese EEZ. From this model, weekly landings-per-unit-effort time series were estimated by region for the period 2005-2007 and compared using a non-parametric statistical test. Percentages of discarded species, in number and weight, were calculated and reveal consistently low figures. These discards seem to depend on the number of hooks, soaking time and depth.

Keywords: LPUE, fishing regime, deep-water, longline, discards, GLM, time-series.

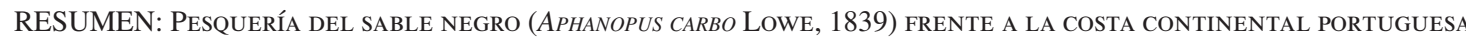
Y LA ISLA DE MADEIRA. - Durante varias décadas, el sable negro (Aphanopus carbo) ha sido un recurso valioso para las comunidades de pesca de Madeira y más recientemente para las comunidades de pesca de Portugal continental. La evaluación del estado de explotación de la especie se inició a finales del siglo XX y se realizó separadamente para dos áreas de la Zona Económica Exclusiva (ZEE) portuguesa. Hoy en día, los estudios de evaluación de stock de la especie son, por lo general, conducidos por grupos de trabajo científicos pertenecientes a organizaciones pesqueras regionales; ICES analiza datos de las pesquerías de las aguas continentales mientras que CECAF trabaja con los datos pertenecientes a la pesquería de Madeira. Este trabajo representa el primer intento de reunir, en un único análisis, la información disponible de las dos pesquerías de palangre que capturan el sable negro en aguas portuguesas. Se realizó una descripción de las características técnicas de las dos flotas y se desarrolló un modelo único para la estandarización del esfuerzo de pesca dirigido a la especie en la ZEE portuguesa. A partir de este modelo, se estimaron series temporales de desembarques semanales por unidad de esfuerzo para esta región durante el periodo 2005-2007, y se compararon utilizando una prueba estadística no paramétrica. Se espera que los resultados, alcanzados gracias a la reciente cooperación entre las Organizaciones Regionales de Pesca, ayuden a entender el papel del llamado "componente sur" del stock en la dinámica de población de la especie. Los porcentajes de especies descartadas, en número y en peso, fueron bajos, y parecían depender del número de anzuelos, tiempo de permanencia en el agua y profundidad.

Palabras clave: LPUE, régimen de pesca, aguas profundas, palangre, descartes, GLM, series temporales. 


\section{INTRODUCTION}

The black scabbardfish (Aphanopus carbo Lowe, 1839) has been mostly recorded on continental slopes from $200 \mathrm{~m}$, west of the British Isles and around Iceland, to $1800 \mathrm{~m}$ south of Madeira and $2300 \mathrm{~m}$ around the Canary Islands (Pajuelo et al., 2008). However, it has also been described in the vicinity of isolated island groups and seamounts (Martins and Ferreira, 1995). Though the species has been recorded in the Indian and Pacific Oceans (Fitch and Gotshall, 1972; Parin, 1986), its occurrence is only documented for the North-Atlantic area (Nakamura and Parin, 1993).

This species has been traditionally caught in Portuguese waters by line gears. The first known artisanal handline fishery for the species started around Madeira Island, where the narrow continental shelf area and the existence of steep slopes have largely contributed to the early emergence of deep-sea fish catches. In continental waters, the fishery for black scabbardfish has developed around the Sesimbra landing port located near the abrupt slopes below Cape Espichel, where the shelf is also narrow. This species is actually the most important fishery resource of Madeira and one of the most valuable deepwater resources landed on the mainland. Landings of the species in Madeira reached a maximum value of 4430 tonnes in 1998 and steadily decreased to 2922 tonnes in 2007, corresponding to $€ 5351$ thousand in 1998 and $€ 7715$ thousand in 2007 . On the mainland, landings showed the largest increase, up to 4520 tonnes, between 1990 and 1993, but decreased rapidly to about 3400 tonnes in 1994 . In recent years, landing figures have fluctuated around 3000 tonnes. Annual revenues of nearly $€ 6000$ thousand have been recorded since 2000 (Bordalo-Machado and Figueiredo, 2009). Regarding discards, preliminary studies indicated already very low percentages ( $c a$. $6 \%$ in weight) for the mainland fleet (in working documents presented to the ICES Working Group on the Assessment of Deep-Sea Fisheries in 2006 and 2008). Discarded species were mainly noncommercial species.

Catches of black scabbardfish have also been reported by French trawlers in northern Europe, west of the British Isles, since the early 1990s, following the development of a multi-species trawl fishery for the roundnose grenadier (Coryphaenoides rupestris), the black scabbardfish, the orange roughy (Hoplostethus atlanticus) and deep-water sharks (Holley and Marchal, 2004). In the early years of this fishery, the black scabbardfish was mostly discarded because no market had developed for the species. However, shortly afterwards, French trawlers adopted a strategy in which the target species varied seasonally according with market demand. At present, this fleet has been reduced considerably due to the low profitability of the species captured (ICES, 2008). Spanish stern bottom freezer trawlers are also known to land a significant by-catch of this species (ICES, 2008).

The life cycle of the black scabbardfish is still poorly understood, with only two spawning areas reported in the literature for the whole NE Atlantic: one around Madeira (Figueiredo et al., 2003) and the other around the Canary Islands (Pajuelo et al., 2008). Early life stages are still unknown and juveniles are rarely caught. However, the species is known to mature between $1000 \mathrm{~mm}$ (Figueiredo et al., 2003) and $1100 \mathrm{~mm}$ (Pajuelo et al., 2008), and attains a maximum age of 12 years based on whole otolith readings (Morales-Nin et al. 2002; Vieira et $a l .$, ). The relatively few studies available on diet composition indicate that the species feeds mainly on fish, squid and crustaceans (Nakamura and Parin, 1993; Santos, 2000).

The black scabbardfish is presently one of the most important commercial deep-water resources dealt with by the ICES Working Group in the Biology and Assessment of Deep-sea Fisheries Resources (WGDEEP). The scientific advice produced by ICES on the exploitation status of the species has been a valuable scientific source for the European Union to establish member states' biannual quota regimes in last four years. Despite the research progress made on some aspects of the species biology and related fisheries, there is still a great lack of scientific evidence to support the currently assumed hypothesis of a single stock in the NE Atlantic (Figueiredo et al., 2003; ICES 2006 (b)). Notwithstanding, for assessment purposes the WGDEEP considers a north component that comprises the multi-species trawl fisheries operating in sub-areas VI and VII and a south component that includes the longline fishery of mainland Portugal in division IXa (ICES, 2001). In effect, it is known that the species experiences different exploitation regimes within the NE Atlantic and shows differences in its length structure between northern and southern regions. Aiming to propose suitable strategy for the conservation of this resource in the Portuguese EEZ, the research project APHACARBO 
funded by the Portuguese Foundation for Science and Technology was initiated in mid-2005 with a 3 -year duration. This project involved the participation of research institutions from different parts of the Portuguese territory, including the mainland, Madeira and the Azores. One of the main objectives of the project is to develop a CPUE model to improve understanding of the temporal evolution of the resource status in Portuguese waters.

The present work intends to describe the longline fisheries targeting black scabbardfish in Portuguese waters in both ICES and CECAF areas and to develop a model for obtaining standardised effort estimates of the species to be used in future assessment studies. Fishing strategies were compared by area and the variation of fishing effort targeting the species in both areas was analysed for the period 2005-2007. The percentages of discarded and landed species in numbers and weight in relation to total catch for each trip are presented for the mainland fishery. The technical factors that may interfere with discards and sources of discards variation were also investigated. Finally a non-parametric test was conducted to determine whether LPUE series from the two regions were originated by the same stochastic process and can thus be considered as part of the same stock.

\section{MATERIALS AND METHODS}

\section{Fisheries characterization}

The data analysed came from different sources and regions in the Portuguese EEZ (Fig. 1). Information on the longline fishery operating on the Portuguese continental slope was retrieved from interviews with vessel skippers, logbooks (when available) and the fisheries data bank of the Portuguese DirectorateGeneral of Fisheries. All the data analysed from the Madeira fishery were obtained from the Madeira Fisheries Directorate for the period 2005-2007, and in particular from three different databases: one containing the daily landings of black scabbardfish by
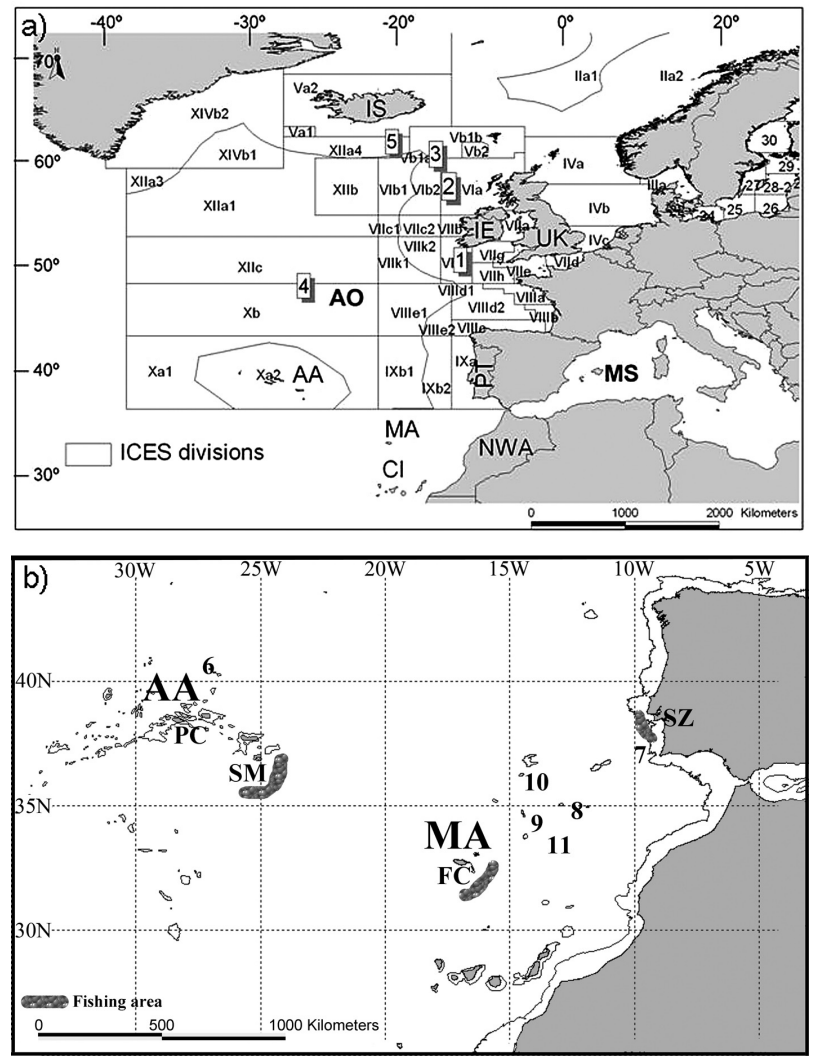

FIG. 1. - a) Map of the northeast Atlantic with the ICES divisions and b) the southern northeast Atlantic with the sampling locations of black scabbardfish and the $1000 \mathrm{~m}$ isobath. AA, Azores Archipelago; AO, Atlantic Ocean; CI, Canary Islands; FC, Funchal; IE, Ireland; IS, Iceland, MA, Madeira Archipelago; MS, Mediterranean Sea; NWA, Northwest Africa; PC, Pico Island; PT, mainland Portugal; SM, Santa Maria Island; SZ, Sesimbra (mainland Portugal); UK, United Kingdom; 1, Porcupine Seabight; 2, Rockall Trough; 3 , Hatton Bank; 4, Faraday seamount; 5, Reykjanes Ridge; 6, Sedlo seamount; 7 , Gorringe seamount; 8 , Ampère seamount; 9 , Unicorn bank; 10, Lion seamount; 11, Seine seamount.

vessel, one containing the technical characteristics of the fishing vessels by year, and one containing information retrieved from logbooks. The complete list of data types analysed in this study is presented in Table 1.

Based on the information available, a brief description of each fishery was conducted from the 1980s to the present and included fleet characteristics, fishing strategy and gear. No two vessels have the same fishing power, as the effective

TABLE 1. - Summary of the data types analysed by source, year and region

\begin{tabular}{|c|c|c|c|c|c|c|}
\hline \multirow[t]{2}{*}{ Data source } & \multicolumn{2}{|c|}{2005} & \multicolumn{2}{|c|}{2006} & \multicolumn{2}{|c|}{2007} \\
\hline & Madeira & Mainland & Madeira & Mainland & Madeira & Mainland \\
\hline Madeiran Fisheries Directorate & $\mathrm{L}, \mathrm{T}$ & & $\mathrm{L}, \mathrm{T}$ & & $\mathrm{L}, \mathrm{T}$ & \\
\hline Vessel's logbooks & $\mathrm{E}$ & E & $\mathrm{E}$ & & $\mathrm{E}$ & \\
\hline Directorate-General for Fisheries & & $\mathrm{L}, \mathrm{T}, \mathrm{E}$ & & $\mathrm{L}, \mathrm{T}, \mathrm{E}$ & & $\mathrm{L}, \mathrm{T}, \mathrm{E}$ \\
\hline Interviews with fleet skippers & & $\mathrm{F}$ & & $\mathrm{F}$ & & $\mathrm{F}$ \\
\hline
\end{tabular}


effort expended results from the contribution of a myriad of factors, some of them not easily quantifiable (Bordalo-Machado, 2006). In the case of the present longline fisheries, data is avaiable on the technical features of three vessels, gross tonnage $(\mathrm{T})$, engine power $(\mathrm{kw})$ and length-over-all (LOA, in $\mathrm{m}$ ), which have previously been shown to influence the variability of landings-per-unit-effort (LPUE) values of black scabbardfish from ICES division IXa (Bordalo-Machado and Figueiredo, 2009). To find groups of vessels showing similar characteristics, a hierarchical cluster analysis was performed using the Ward and complete linkage agglomeration methods. For the distances between the pairs of vessel characteristics, four types were calculated: Manhattan, Euclidean, Euclidean squared and Chebychev. Results were evaluated using the cophenetic correlation coefficient and the Hubert $\Gamma$ statistic (Haldiki et al., 2002). Cluster analysis was performed in the $\mathrm{R}$ statistical environment ( $\mathrm{R}$ Development Core Team, 2006).

\section{Fishing effort standardisation}

In order to obtain standardised estimates of fishing effort targeting black scabbardfish in Portuguese waters, a generalised linear model (GLM) was fitted to weekly LPUE data from both fisheries in the period 2005-2007. Due to the information deficiencies of both fleets regarding the number of hooks used per haul, the nominal effort was calculated for each vessel as the number of hauls conducted per week. The backward stepwise regression method was applied to select the best set of explanatory variables based on the AIC criterion (Akaike, 1973; Hastie and Pregibon, 1992). The standardisation considers year and month effects, the two fishing regions and the group of vessels based on the clustering results. The model's goodness of fit was evaluated by graphic analysis of residuals.

\section{Discards}

Onboard discard samples from the black scabbardfish longline fleet of mainland Portugal have been collected since mid-2005 and are part of the Portuguese discard sampling programme, included in the European Commission Data Collection Regulation (DCR)/National Programme (NP). Monthly samples were programmed, but due to several constraints only 14 trips were sampled from July 2005 to September 2008, unevenly distributed by year, quarter, fishing ground and vessel. These trips were sampled in three co-operative vessels about 20 metres long, and were distributed in 2 fishing grounds on the Portuguese continental slope. The first, which sampled 10 trips, is located off Figueira da Foz (Longitude $10^{\circ} 06^{\prime}-09^{\circ} 30^{\prime} \mathrm{W}$; Latitude $39^{\circ} 52^{\prime}$ $40^{\circ} 30^{\prime} \mathrm{N}$ ) and the second, which sample 4 trips, is located off Sesimbra (Longitude $09^{\circ} 36^{\prime}-09^{\circ} 15^{\prime} \mathrm{W}$; Latitude $\left.38^{\circ} 12^{\prime}-38^{\circ} 24^{\prime} \mathrm{N}\right)$. Hook numbers 5, 6 and 8 were used on the sampled trips, baited with sardine in $90 \%$ of the cases and horse mackerel in the remaining cases.

Soaking time was calculated as the time between end of setting and beginning of hauling. Depth values presented in this paper correspond to an average of initial and final setting depths. Descriptive statistics of these variables and the number of hooks set on the sampled trips are presented in Table 5.

During sampling onboard, each caught specimen was identified and counted by category: target species (Aphanopus carbo), by-catch and discarded. A sub-sample of discarded specimens was kept and examined later in the laboratory. Haul information per fishing trip (temporal and spatial limits of setting and hauling operations, fishing depth, hook number and total number of hooks set) and information on the condition of target species specimens (i.e. whether or not they were damaged) were recorded. At the fish market, data on fishing trip landings were also collected.

Relative percentages of total discarded and landed species in number and weight were calculated for each trip. Factors that might be related to discard quantities, such as year, quarter, vessel, fishing ground and hook number, were not analysed because only 14 trips were sampled. Trip allocation in all these variables would result in many null observations and, as reported by Bordalo-Machado and Figueiredo (2009), the longline fishery for black scabbardfish shows little variability in vessel technical characteristics, gears, diversity of landed species and fishing strategies. Changes in the percentage of discards in the catch were analysed considering all the species together.

In the case of the proportion of discards in number, a GLM with the binomial family and a canonical link (logit) was fitted. When overdispersion was found, the model was fitted using the quasibinomial family, in which the parameters are estimated using quasi-likelihood (McCullagh and Nelder, 1989). In 
the case of the percentage in weight, several GLMs were essayed: one with the Gamma family and a canonical link (reciprocal), and two with the Gauss family and the two links (identity and $\log$ ). All the computations were done in the $\mathrm{R}$ statistical environment (R Development Core Team, 2006).

\section{LPUE time series comparison}

The non-parametric test conducted to compare the weekly LPUE series of the mainland and Madeira for the period 2005-2007 was proposed by Caiado et al. (2008) for comparisons between two independent and stationary time series. To apply the test it was considered sufficient that the series had second-order stationarity, in which it is only required that the $1^{\text {st }}$ and $2^{\text {nd }}$ moments of a random process are invariant with respect to time. Stationarity was graphically evaluated using plots of the mean and variance of the LPUE calculated per quarter for each region.

The test requires the determination of the normalised periodogram $\mathrm{NP}\left(\omega_{\mathrm{r}}\right)$ for each LPUE series, which is obtained after the division by the sample variance. The periodogram is considered to be an empirical estimator of the spectral density $F\left(\omega_{\mathrm{r}}\right)$ of a time series and yield information about the frequency of its periodic events.

For two stationary time series, $\mathrm{y}_{\mathrm{t}}$ and $\mathrm{x}_{\mathrm{t}}$, the null hypothesis to be tested is $\mathrm{H}_{0}: F_{\mathrm{x}}\left(\omega_{\mathrm{r}}\right)=F_{\mathrm{y}}\left(\omega_{\mathrm{r}}\right)$, which means that there is no difference between the underlying spectra of the series $y_{t}$ and $x_{t}$ for all Fourier frequencies $\omega_{\mathrm{r}}$. The same applies to the normalised periodograms of $y_{t}$ and $x_{t}$; these can be compared through the $\mathrm{D}_{\mathrm{NP}}$ statistic, which under the null hypothesis is approximately normally distributed with zero mean and unit variance (Caiado et al., 2008).

The significance level adopted for the test was $\alpha=0.05$, i.e. the null hypothesis is not statistically rejected if $\mathrm{D}_{\mathrm{NP}}$ falls within the interval [-1.96, 1.96].

\section{RESULTS}

\section{Fisheries description}

\section{Mainland}

The fishery for black scabbardfish in Portuguese mainland waters started in the early 1980s. The fleet comprised small artisanal vessels, having an average LOA of around $11 \mathrm{~m}$, an engine power of $c a .96 \mathrm{kw}$ and a gross registered tonnage of 16.6 t. Between 1992 and 1995, the average values of the vessels' technical characteristics increased to $16.3 \mathrm{~m} \mathrm{LOA}$ and $137 \mathrm{kw}$ engine power. In 2002 and 2003, larger vessels entered the fleet, resulting in a new rise in average values to $308 \mathrm{kw}$ engine power, $17 \mathrm{~m} \mathrm{LOA}$ and $45 \mathrm{t}$ gross tonnage. The number of vessels in the fleet reached a maximum in 1986 (28) and decreased to 15 in 2004. At present, fleet size remains below 20 , with more than $95 \%$ of the vessels registered in Sesimbra port.

Fishing gear design was modified from traditional Madeira longline gears. This gear is composed by a horizontal bottom longline with alternating floats and sinkers at constant intervals on the main line. The number of hooks used per gear rose from 3600 in the early years of the fishery to more than 9000 in 2004. No. 5 hooks with sardine (Sardina pilchardus) as the bait are commonly used in fleet vessel gears.

Fishing usually starts at dusk, when vessels leave the port and steam offshore for a period that varies between 1 and almost 6 hours. At the fishing ground, two operations generally occur: 1) a newly baited longline gear is deployed into the sea and set, and 2) another longline gear previously set in the last 24-48 $\mathrm{h}$ (average around $38 \mathrm{~h}$ ) is recovered with the aid of a hauling winch. According to the information collected during the discard sampling programme, the setting operations usually takes 2 hours and the hauling operations between 8 and 15 hours. Fishing takes place on hard bottoms along the Portuguese continental slopes at depths ranging from 800 to $1450 \mathrm{~m}$.

For a more detailed description of this fishery see Bordalo-Machado and Figueiredo (2009).

\section{Madeira}

In the early 1980s, the Madeiran black scabbardfish fleet was characterised by small artisanal vessels (6 m LOA on average) that operated near the coast. In 1988 there were 95 vessels. The number of vessels progressively decreased with time, the most drastic change being observed between 1990 and 1995, when the number of vessels dropped from 84 to 44 . During the period 1998-2000, the fleet comprised $c a$. 40 vessels (on average $13 \mathrm{~m} \mathrm{LOA}, 19 \mathrm{GT}$ and $150 \mathrm{Hp}$ ) (Reis et al., 2001). Fleet size continued to decrease to around 30 in the most recent years (2005-2007), with no significant changes in their technical characteristics. 

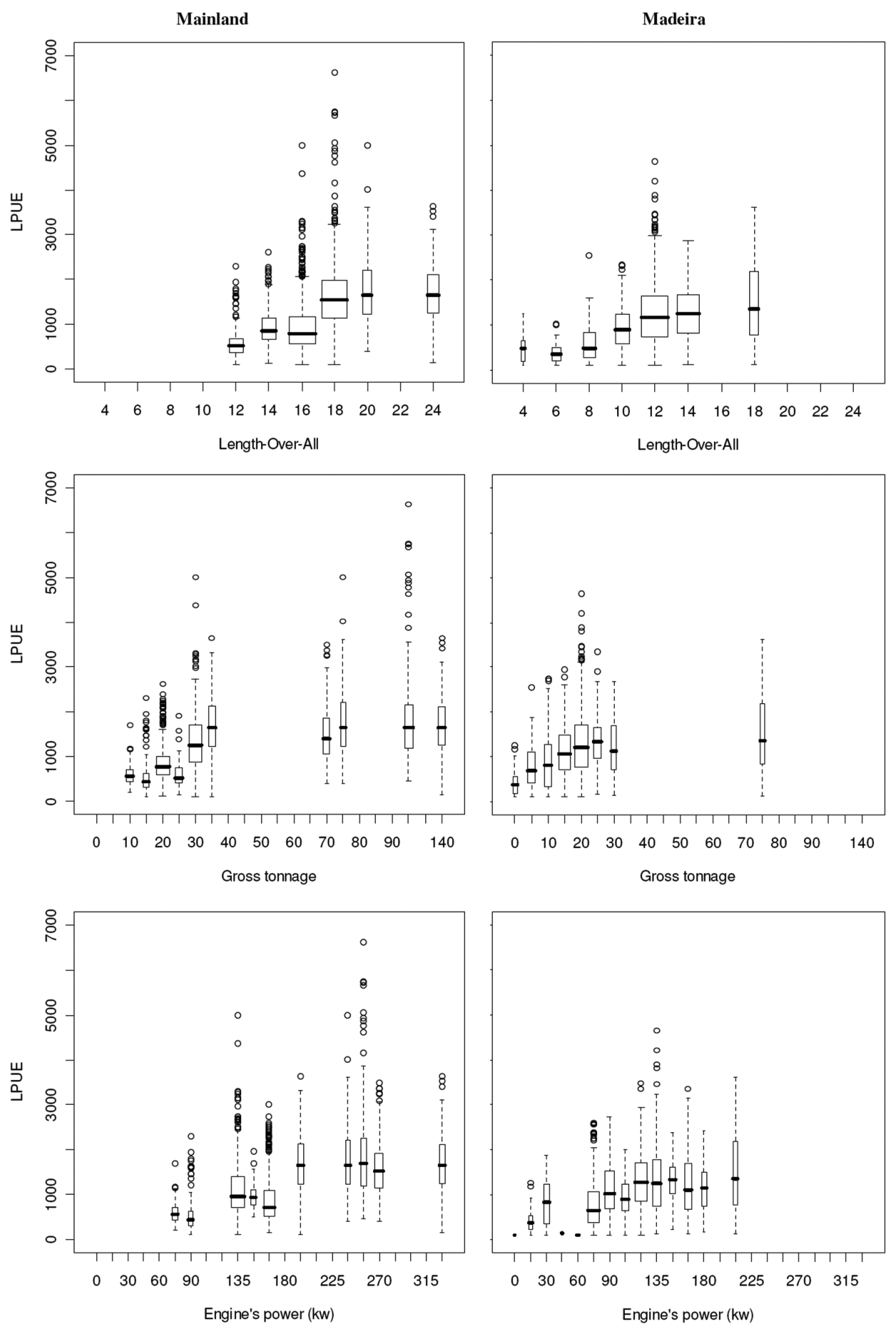

FIG. 2. - Black scabbardfish LPUE box-plots by length-over-all, engine's power and tonnage for vessels from mainland Portugal and Madeira fleets.

The fishing gear used in the black scabbardfish fishery in the last few decades is a mid-water horizontal drifting longline, set in the water column usually at depths of $1000 \mathrm{~m}$. Few changes have been recorded in this period, being mainly related to the increase in the number of hooks used in the sets and the fishing strategy. The number of hooks per set has increased from
4000-5000 (Merret and Haedrich, 1997) to an average of 7000-8000 hooks at present. Steel No 6 hooks are used, usually baited with salted squid slices (Ommastrephes sp.) or filets of horse mackerel (Trachurus picturatus) and mackerel (Scomber japonicus). The fishing operations described by Merret and Haedrich (1997) have remained almost unchanged to the present time. 
The number of fishing days per fishing trip increased from 2-3 in the 1990s (Reis et al., 2001) to 5-7 at present. This is apparently due to fishermen's recent endeavours to exploit more distant fishing grounds. The fleet now exploits new areas, especially located SE of Madeira, as far as 150-200 nautical miles from the fishing port.

\section{Analysis of vessel characteristics}

Vessel technical characteristics showed differences between fleets in the period 2005-2007 (Fig. 2). In general, Madeiran fleet vessels have small dimensions and lower engine power than mainland fleet vessels. In the cluster analysis, 53 vessels from both fleets were used. The combination of the Chebychev distance with the Complete linkage agglomeration method gave the highest values for both the Cophenetic correlation coefficient and the Hubert $\Gamma$ statistic, 0.6465 (Fig. 3). Clusters 3 and 4 (Fig. 3, Table 2) contain the larger vessels of the two fleets, five from mainland and two from Madeira. All these vessels had a LOA higher than $18 \mathrm{~m}$ and an engine power above $220 \mathrm{kw}$. Cluster 2 includes the smallest vessels of the fleet, one from the mainland and 14 from Madeira. The remaining 31 vessels of the two fleets were grouped in Cluster 1, which has very low variability of LOA and gross tonnage values. These results shows that the technical characteristics used in the analysis could be used to form dissimilar groups of vessels in the fleet that ultimately exhibit different catching powers.

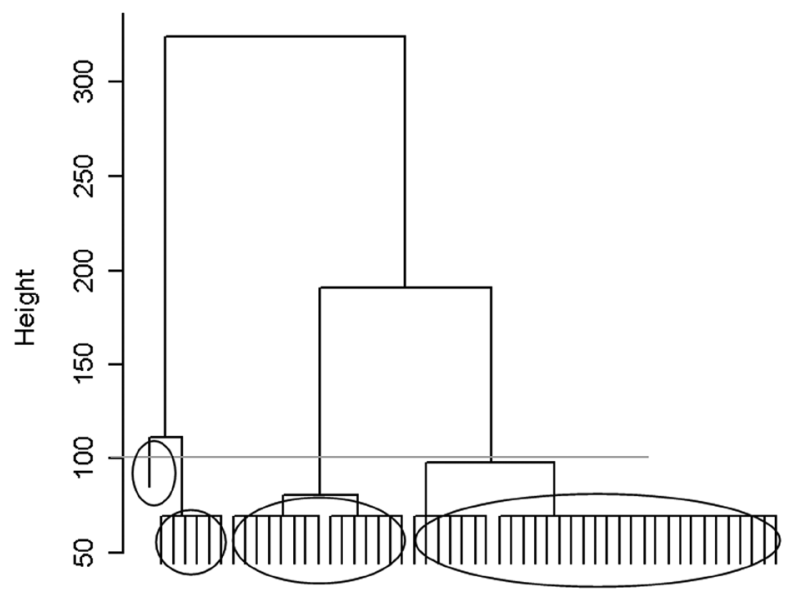

FIG. 3. - Hierarchical cluster analysis dendrogram showing four groups of vessels, from the period 2005-2007, obtained using Complete Linkage agglomeration method and the Chebychev distance. This analysis comprised vessels from both the mainland and Madeira.
TABLE 2. - Descriptive statistics of vessel technical characteristics by the four clusters selected using the data from both fleets. LOA, length-over-all; GT, gross tonnage; POW, engine power.

\begin{tabular}{llcccc}
\hline Cluster & Statistic & LOA & GT & POW & $n$ \\
\hline 1 & Median & 14.7 & 22.2 & 141.7 & 31 \\
& Std. Dev. & 1.844 & 11.515 & 27.344 & \\
2 & Median & 7.2 & 6.7 & 55.9 & 15 \\
& Std. Dev. & 2.310 & 4.809 & 29.583 & \\
3 & & 24.5 & 142.1 & 331.8 & 1 \\
4 & Median & 18.5 & 77.0 & 262.6 & 6 \\
& Std. Dev. & 1.444 & 12.550 & 22.845 & \\
\hline
\end{tabular}

\section{Fishing effort standardisation}

A previous analysis of some available logbook data from the Madeira fleet (not presented) has revealed differences between black scabbardfish catch rates from areas located closer to the island (below $100 \mathrm{~nm}$ distance) and the catch rates from areas located more than $100 \mathrm{~nm}$ from the fishing port. Since at present there is no way to associate weekly LPUE data from this region with a specific area, it was decided to create a subset of vessels from the Madeiran fleet whose technical characteristics are unsuitable for continuous operation in more distant grounds. By doing this, we are assuring that the LPUE in the analysis reflect only the fisheries exploitation regime in one particular area. A total of nine vessels were selected from this subset. This choice was further supported by cluster analysis, as seven of the vessels belong to Cluster 2, which contains the smallest vessels of the fleet, and the technical characteristics of the remaining two are among the lowest of Cluster 1. The summary of the technical characteristics is presented in Table 3. Regarding the mainland fleet, a subgroup was also selected by excluding vessels from Clusters 3 and 4 . These exhibit LOA and LPUE values greater than those observed in Clusters 1 and 2. In addition, vessels from Clusters 3 and 4 operate in areas located farther from the fishing port.

In model fitting, nine vessels from the Madeiran fleet and eight from the mainland fleet were used.

TABLE 3. - Summary of the technical characteristics of Madeiran vessel subset used in fishing effort standardisation. LOA, lengthover-all; GT, gross tonnage; POW, engine power.

\begin{tabular}{lccc}
\hline & LOA & GT & POW \\
\hline Average & 9.4 & 84.6 & 9.2 \\
Std. Dev. & 2.333 & 33.233 & 7.126 \\
\hline
\end{tabular}


TABLE 4. - Results from the LPUE standardisation model. Df, degrees of freedom.

\begin{tabular}{lcccrr}
\hline Factors & Df & Sum Sq & Mean Sq & F value & $\operatorname{Pr}(>\mathrm{F})$ \\
\hline Year & 3 & 89167 & 29722 & 99164.185 & $<2.2 \mathrm{e}-16$ \\
Week & 51 & 48 & 1 & 3.161 & $1.2 \mathrm{e}-12$ \\
Group & 1 & 57 & 57 & 189.893 & $<2.2 \mathrm{e}-16$ \\
Year:Week & 102 & 67 & 1 & 2.192 & $3.1 \mathrm{e}-10$ \\
Week:Region & 52 & 39 & 1 & 2.475 & $4.4 \mathrm{e}-08$ \\
Group:Region & 1 & 2 & 2 & 5.505 & 0.01907 \\
\hline
\end{tabular}

The model selected for effort standardisation had as significant predictors year, week, vessel cluster,

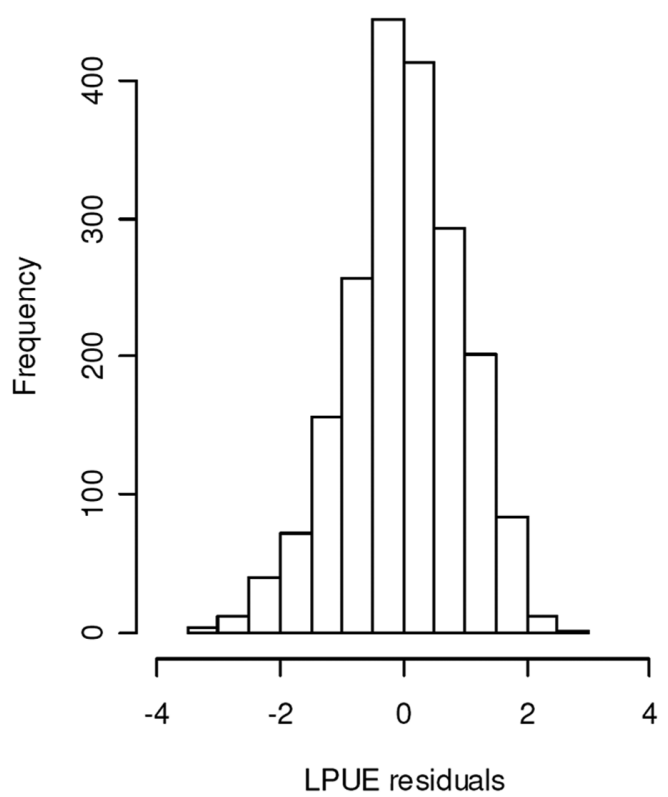

and the interactions year:week, week:region and cluster:region (Table 4). The model explained 99\% of the variability of LPUE values. Both the residuals histogram and the respective normal Q-Q plot of the GLM model (Fig. 4) show that there are no strong violations of the model's assumptions.

LPUE estimates for the mainland and Madeiran fleets were obtained using the effort standardisation model (Fig. 5). The LPUE series from both fleets exhibited values of around $900 \mathrm{~kg} /$ haul for the period 2005-2007. During the second semester of 2007, both fleets showed an increase in LPUE higher than $1200 \mathrm{~kg} /$ haul.

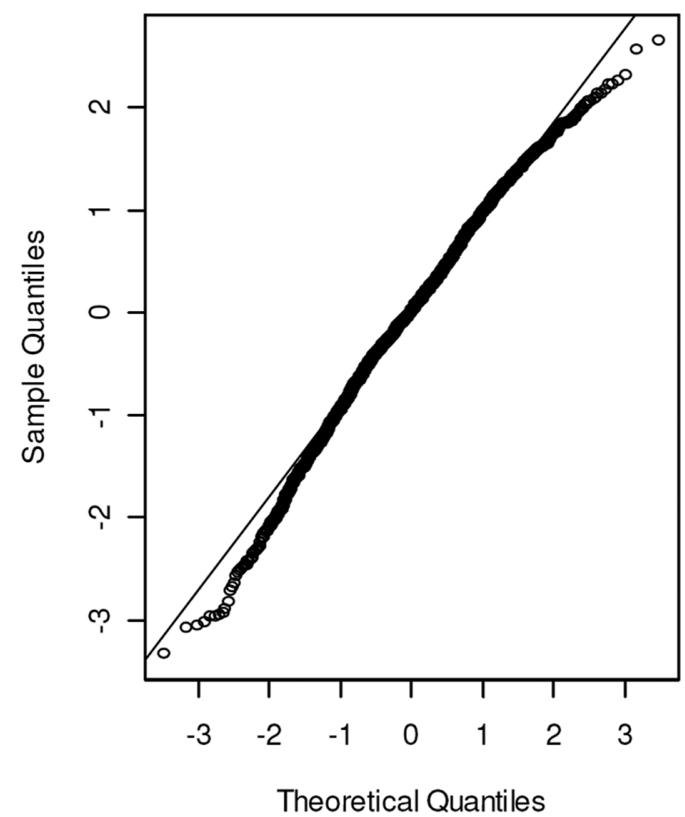

FIG. 4. - Residuals plots for the GLM used to standardise black scabbardfish LPUE.

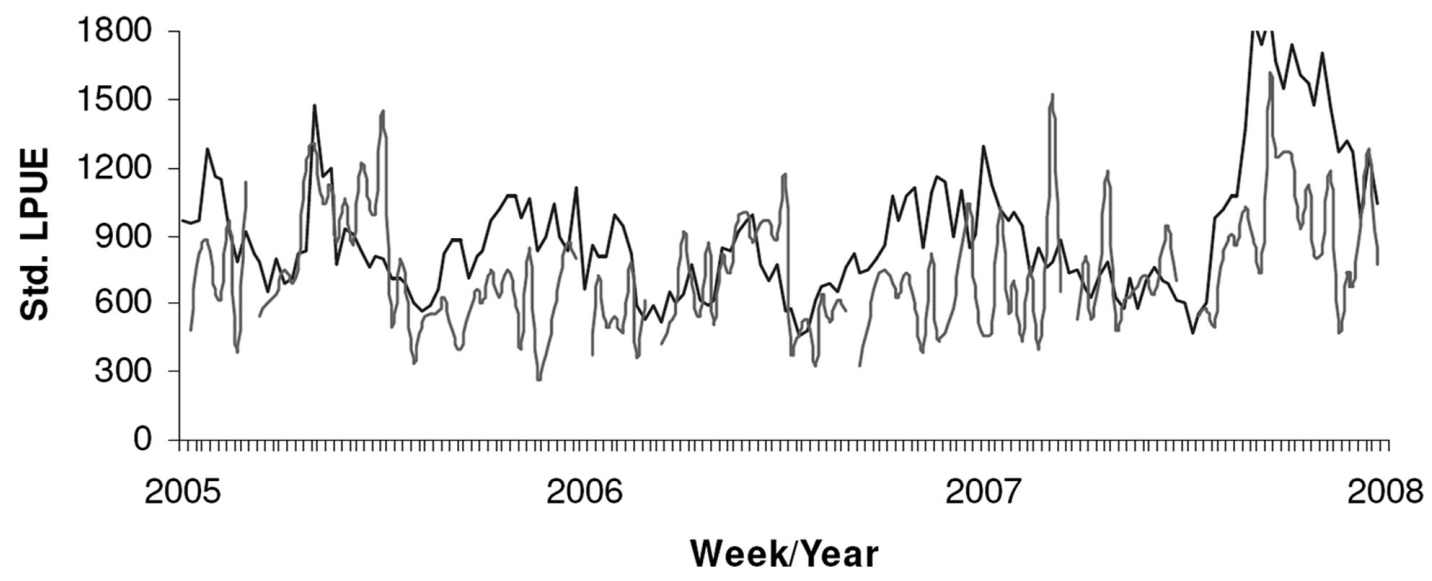

\section{Mainland _ Madeira}

FIG. 5. - Standardised weekly LPUE variation in the period 2005-2007 for mainland Portugal and Madeira. 
TABLE 5. - Descriptive statistics of continuous variables observed on sampled trips $(\mathrm{n}=14)$ onboard longline vessels. Sd, standard deviation.

\begin{tabular}{lcccc}
\hline & Mean & Minimum & Maximum & Sd \\
\hline No. of hooks & 6444 & 4000 & 10000 & 1832 \\
Soak time (h) & 34.1 & 21.5 & 39.7 & 4.81 \\
Depth (m) & 1212 & 115 & 1298 & 60.25 \\
\hline
\end{tabular}

\section{Discards analysis}

Discards percentages in number and weight were very low for the black scabbardfish fishery off the Portuguese continental slope: $6.3 \%$ and $2.2 \%$, respectively. Species occurrence analysis (Table 6) revealed that 23 species were present in discards, baird's smooth-head (Alepocephalus bairdii) (85.7\%) and smooth lanternshark (Etmopterus pusillus) $(78.6 \%)$ being the most frequent species. All the other species were present in less than $50 \%$ of the sampled trips. The species with the highest mean discard percentage was also E. pusillus, with $3.24 \%$ of total catch in numbers, while all the others did not reach $1 \%$ of total catch (only one individual of target species, Aphanopus carbo, was discarded because of its small size). The vast majority of discarded specimens corresponded to non-commercial species, with the exception of small-sized commercial sharks (Centroscymnus coelolepis, C. crepidater, Scymnodon ringens, Prionace glauca). With regard to the percentages of landings in numbers, Table 6 shows that Aphanopus carbo comprised on average $88 \%$ of the longline catches and was present as a target species in all sampled trips. The other frequently landed species were birdbeak dogfish (Deania calcea) $(93 \%)$, the leafscale gulper shark (Centrophorus squamosus) (86\%) and the Portuguese dogfish (Centroscymnus coelolepis) (71\%).

Since observations were collected on only 14 fishing trips, possible differences between years, quarters, vessels and fishing zones were assumed to be not significant. Accordingly, the GLM analysis started by fitting a maximal model (as maximal as possible) with only the following quantitative ex-

TABLE 6. - Descriptive statistics (relative percentage of the total catch) of discarded and landed species numbers and occurrences. Sd, standard deviation.

\begin{tabular}{|c|c|c|c|c|c|c|c|c|c|c|}
\hline \multirow[b]{2}{*}{ Scientific name } & \multirow[b]{2}{*}{ Mean } & \multicolumn{4}{|c|}{ DISCARDS } & \multicolumn{5}{|c|}{ LANDINGS } \\
\hline & & Minimum & Maximum & $\mathrm{Sd}$ & Occurrence & Mean & Minimum & Maximum & $\mathrm{Sd}$ & Occurrence \\
\hline Alepisaurus ferox & 0.04 & 0.00 & 0.41 & 0.11 & 14.3 & & & & & \\
\hline Alepocephalus bairdii & 0.70 & 0.00 & 2.88 & 0.86 & 85.7 & & & & & \\
\hline Aphanopus carbo & 0.01 & 0.00 & 0.07 & 0.02 & 7.1 & 88.16 & 69.36 & 93.28 & 6.46 & 100 \\
\hline Benthodesmus elongates & 0.03 & 0.00 & 0.41 & 0.11 & 7.1 & & & & & \\
\hline Centrophorus granulosus & & & & & & 0.03 & 0.00 & 0.16 & 0.06 & 28.6 \\
\hline Centrophorus lusitanicus & & & & & & 0.01 & 0.00 & 0.10 & 0.03 & 7.1 \\
\hline Centrophorus squamosus & & & & & & 1.55 & 0.00 & 2.97 & 0.90 & 85.7 \\
\hline Centroscymnus coelolepis & 0.03 & 0.00 & 0.41 & 0.12 & 7.1 & 0.77 & 0.00 & 4.54 & 1.45 & 71.4 \\
\hline Centroscymnus crepidater & 0.12 & 0.00 & 0.41 & 0.17 & 42.9 & 0.30 & 0.00 & 2.51 & 0.69 & 35.7 \\
\hline Centroscymnus cryptacanthus & 0.00 & 0.00 & 0.06 & 0.02 & 7.1 & & & & & \\
\hline Coryphaena hippurus & 0.01 & 0.00 & 0.07 & 0.02 & 7.1 & & & & & \\
\hline Coryphaenoides rupestris & 0.01 & 0.00 & 0.12 & 0.03 & 7.1 & & & & & \\
\hline Dalatias licha & 0.00 & 0.00 & 0.06 & 0.02 & 7.1 & & & & & \\
\hline Deania calcea & & & & & & 1.69 & 0.47 & 3.62 & 0.90 & 92.9 \\
\hline Deania profundorum & & & & & & 0.01 & 0.00 & 0.10 & 0.03 & 14.3 \\
\hline Epigonus telescopus & & & & & & 0.02 & 0.00 & 0.28 & 0.08 & 7.1 \\
\hline Etmopterus pusillus & 3.24 & 0.00 & 8.91 & 3.13 & 78.6 & & & & & \\
\hline Etmopterus spinax & 0.52 & 0.00 & 3.42 & 1.14 & 35.7 & & & & & \\
\hline Galeus melastomиs & 0.16 & 0.00 & 1.85 & 0.51 & 14.3 & 0.01 & 0.00 & 0.10 & 0.03 & 7.1 \\
\hline Hexanchus griseus & & & & & & 0.02 & 0.00 & 0.28 & 0.08 & 7.1 \\
\hline Isurus oxyrinchus & 0.01 & 0.00 & 0.07 & 0.02 & 7.1 & & & & & \\
\hline Lepidion guentheri & 0.06 & 0.00 & 0.41 & 0.15 & 14.3 & & & & & \\
\hline Lepidion spp. & 0.03 & 0.00 & 0.41 & 0.11 & 7.1 & & & & & \\
\hline Loliginidae, Ommastrephidae & & & & & 0 & 0.00 & 0.00 & 0.06 & 0.02 & 7.1 \\
\hline Nesiarchus nasutus & 0.07 & 0.00 & 0.41 & 0.15 & 21.4 & & & & & \\
\hline Phycis blennoides & 0.07 & 0.00 & 0.62 & 0.18 & 14.3 & 0.22 & 0.00 & 0.84 & 0.29 & 64.3 \\
\hline Prionace glauca & 0.03 & 0.00 & 0.28 & 0.08 & 21.4 & 0.05 & 0.00 & 0.56 & 0.15 & 14.3 \\
\hline Raja spp. & 0.01 & 0.00 & 0.14 & 0.04 & 7.1 & 0.01 & 0.00 & 0.08 & 0.02 & 7.1 \\
\hline Scymnodon ringens & 0.05 & 0.00 & 0.28 & 0.09 & 28.6 & 0.85 & 0.00 & 5.85 & 1.61 & 64.3 \\
\hline Somniosus microcephalus & & & & & & 0.00 & 0.00 & 0.06 & 0.02 & 7.1 \\
\hline Synaphobranchus kaupii & 0.48 & 0.00 & 3.06 & 0.90 & 50 & & & & & \\
\hline $\begin{array}{l}\text { Thunnus alalunga } \\
\text { Trachvrincus scabrus }\end{array}$ & & & & & & 0.01 & 0.00 & 0.07 & 0.02 & 7.1 \\
\hline $\begin{array}{l}\text { Trachyrincus scabrus } \\
\text { Xiphias gladius }\end{array}$ & 0.08 & 0.00 & 0.41 & 0.15 & 28.6 & 0.00 & 0.00 & 0.06 & 0.02 & 7.1 \\
\hline
\end{tabular}



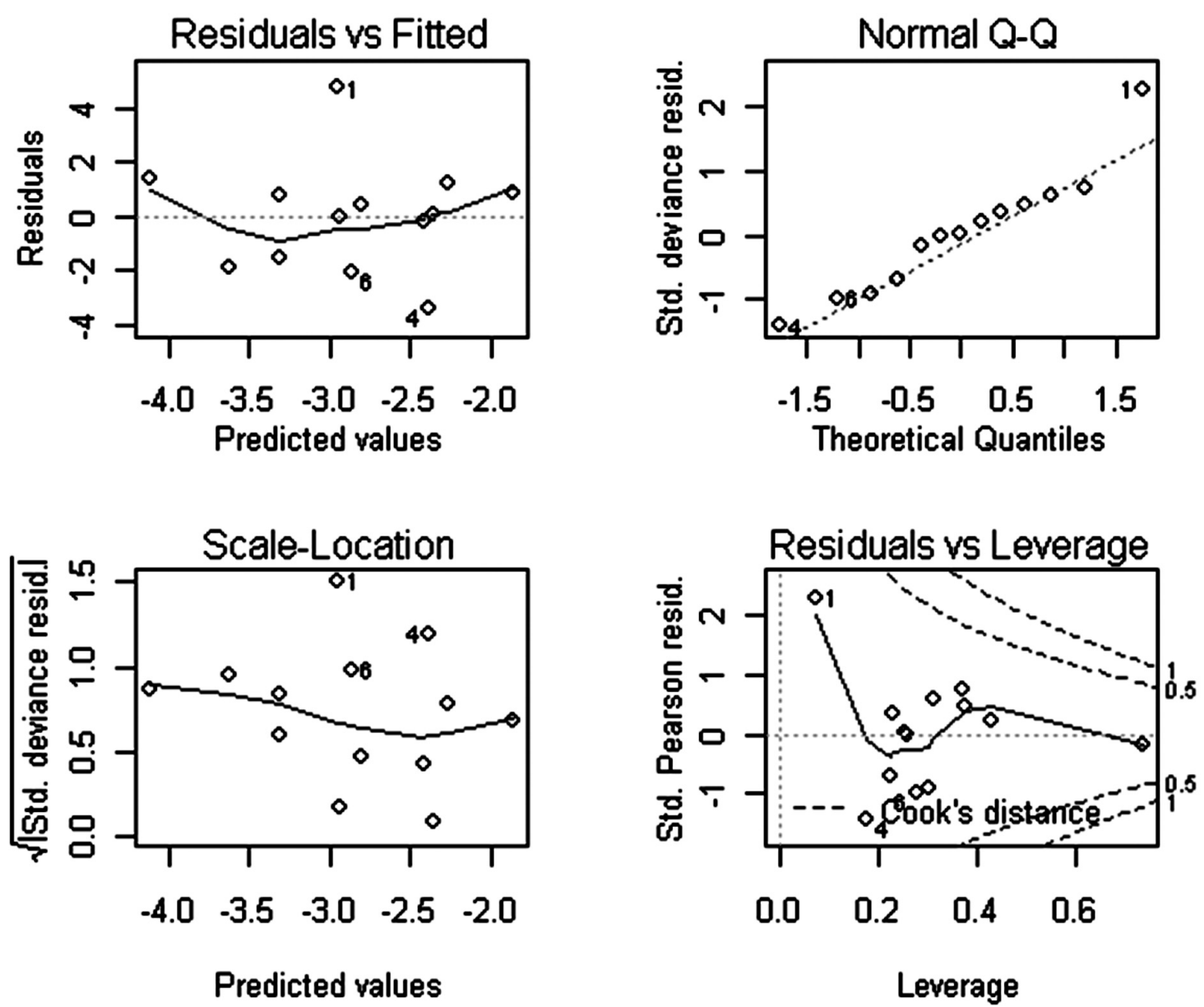

FIG. 6. - Residual plots of the main effects model fitted to proportion of discards in number (family binomial canonical link).

planatory variables: number of hooks, soaking time and mean depth.

In the case of the proportion of discards in number, a GLM was first run with the binomial family, but had to be run again with the quasi-binomial family due to the existence of over-dispersion.

The maximal model was updated by removing the terms that were not significant. The update began with the removal of the three-way interaction and then the successive removal of the least significant two-way interactions. In the end, a model with only the main effects was obtained. Figure 6 shows (top left) its deviance residuals on the y axis against the fitted values on the $\mathrm{x}$ axis, (top right) the Normal "quantile-quantile plot", (bottom left) the square root of the deviance residuals against the fitted values and (bottom right) the standardised deviance residuals against the leverage of each datum and also the Cook's distance (Wood, 2006). None of the plots were a cause of concern. The observed pattern is expectable considering
TABLE 7. - Coefficient estimates and their standard errors. $t$ value and p-value of the null hypothesis (the parameter $=0$ ) test of the main effects model fitted to proportion of discards in number

\begin{tabular}{lrrrl}
\hline & Estimate & Std. Error & $\mathrm{t}$ value & $\operatorname{Pr}(>|\mathrm{t}|)$ \\
\hline (Intercept) & $-6.306 \mathrm{e}+00$ & $2.847 \mathrm{e}+00$ & -2.215 & $0.054038+$ \\
Nr of Hooks & $-3.928 \mathrm{e}-04$ & $7.995 \mathrm{e}-05$ & -4.913 & $0.000832 * * *$ \\
Depth & $6.639 \mathrm{e}-03$ & $2.156 \mathrm{e}-03$ & 3.080 & $0.013140 *$ \\
Soak time & $-6.387 \mathrm{e}-02$ & $2.371 \mathrm{e}-02$ & -2.693 & 0.024668 \\
\hline
\end{tabular}

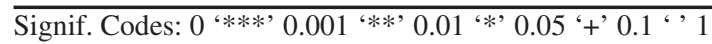
(Dispersion parameter for quasibinomial family taken to be 5.761503)

Null deviance: 219.876 on 12 degrees of freedom

Residual deviance: 48.998 on 9 degrees of freedom

the low number of sampled trips. The parameters of this model are presented in Table 7. Analysis of deviance indicates that the model explains $78 \%$ of the total variation of the proportion of discards in number.

In the case of the percentage of discards in weight, three models were fitted: Gamma with reciprocal link, Gauss with identity link and Gauss with log link. The latter was the one that explained the high- 

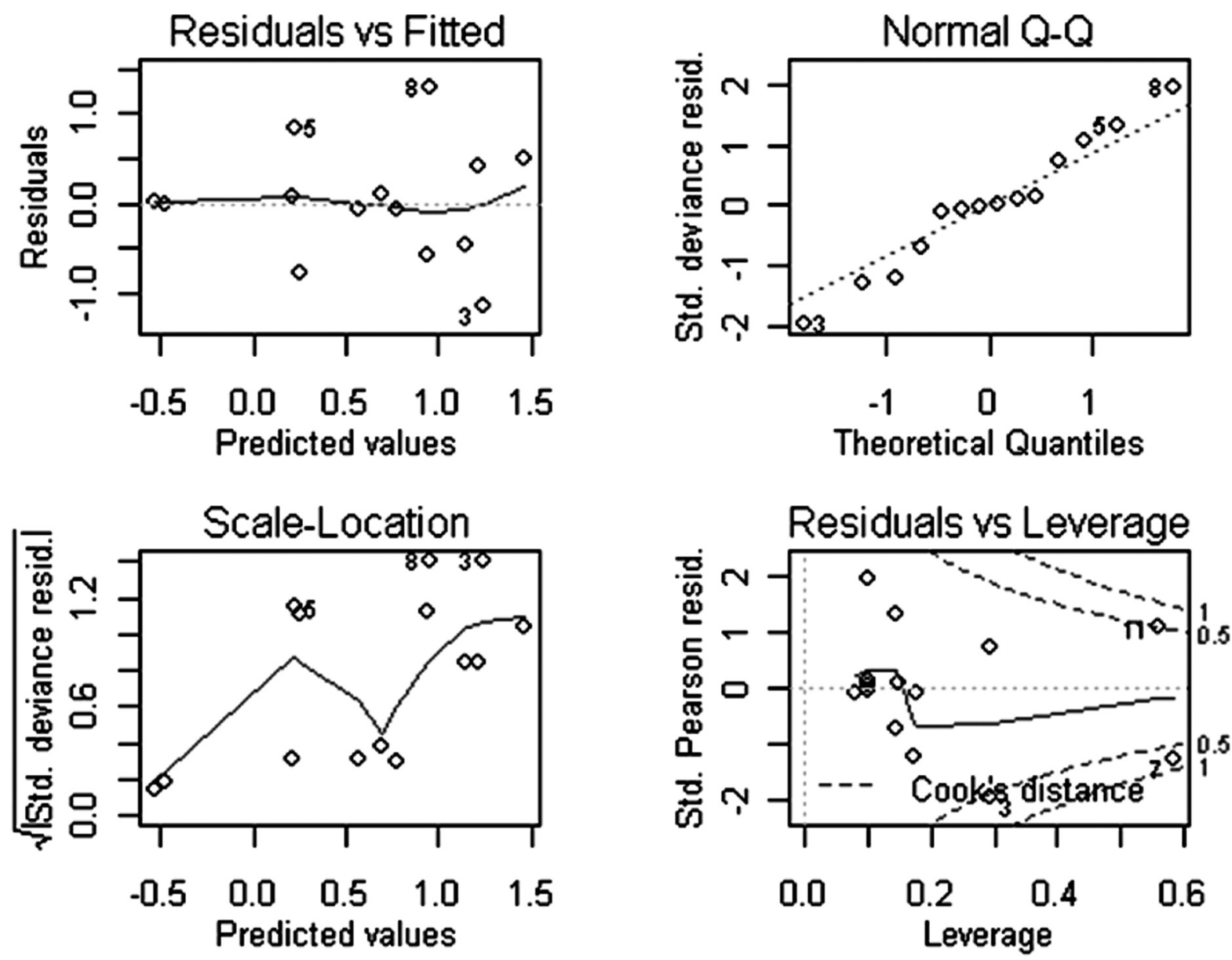

FIG. 7. - Residual plots of the main effects model fitted to percentage of discards in weight (Gaussian family log link).

TABLE 8. - Coefficient estimates and their standard errors. $t$ value and the $p$-value of the null hypothesis (the parameter $=0$ ) test of the model fitted to the percentage of discards in weight

\begin{tabular}{lrll}
\hline & Estimate & Std. Error & $\operatorname{Pr}(>|\mathrm{t}|)$ \\
\hline Nr of Hooks & -0.0004 & 0.0001 & $0.00112 * *$ \\
Depth & 0.0040 & 0.0009 & $0.00068 * *$ \\
Soak time & -0.0535 & 0.0196 & $0.01971 *$
\end{tabular}

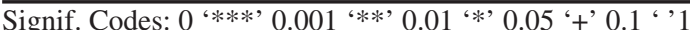

(Dispersion parameter for gaussian family taken to be 0.4879107 )

Null deviance: 21.6036 on 13 degrees of freedom

Residual deviance: 5.367 on 11 degrees of freedom

est percentage of data variability. Its parameters are presented in Table 8 . The deviance residual plots are shown in Figure 7 and may be considered acceptable. Analysis of deviance indicates that the model explains $75 \%$ of the total variation of the percentage of discards in weight.

For the other models-Gamma with reciprocal link and Gauss with identity link - the same procedure was followed, and models with only the main effects were obtained, each explaining $70 \%$ of the total variation in the percentage of discards in weight.

\section{LPUE time series comparison}

No marked tendencies were observed in the mean and variance by quarter curves of the LPUE time series (Fig. 8), which is a good indication to assume second-order stationarity. The value obtained for the non-parametric test was -4.2103 , which leads to the rejection of the null hypothesis at a confidence level of $\alpha=0.05$. Based on this result, it is accepted that different stochastic processes have generated the LPUE time series of each fishing fleet. However, if we consider the hypothesis of a single stock of the species in the NE Atlantic and the existence of horizontal migrations, we can assume that the differences in the stochastic processes of the two regions are due to a temporal gap of the species life-cycle. In effect, it is expected that higher yields occur first in the Madeira region, where a spawning area is 

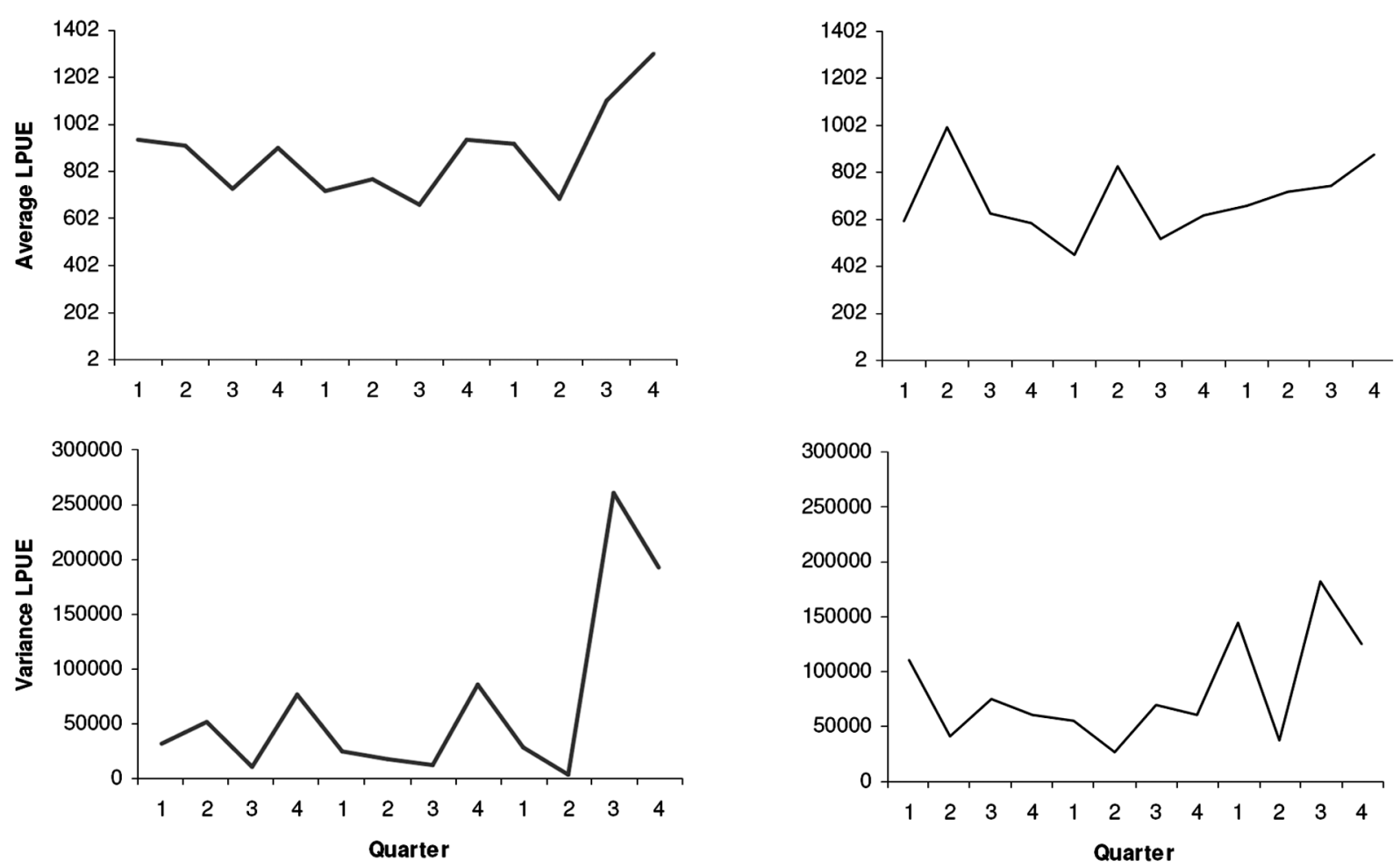

FIG. 8. - Mean and variance by quarter curves of standardised LPUE from each region in the period 2005-2007.

confirmed (Figueiredo et al., 2003) and only later in mainland waters.

By considering the above hypothesis and assuming a time gap of 12 weeks ( $\mathrm{ca}$. three months) between the two regions, the time series from the Madeira region was restructured to make the $13^{\text {th }}$ value in chronologic order correspond to the beginning of the series. Furthermore, the series from the mainland was truncated in the $41^{\text {st }}$ position. Using these new time series, the $\mathrm{D}_{\mathrm{NP}}$ statistic value obtained was -1.409 , which does not reject the null hypothesis at a level of confidence of $\alpha=0.05$; the same stochastic process originated the two LPUE time series.

\section{DISCUSSION}

There are presently more vessels engaged in the catch of black scabbardfish off Madeira than off the mainland. Despite the different fleet sizes observed in the two fisheries, the annual landings of the species have been similar in the last few years, with figures of around 3000 tonnes.

The fishing vessels of the mainland fishery have, on average, a larger size and engine power than the vessels from the Madeiran fishery. The fishing strategy is also different between the fleets. Whereas mainland vessels usually perform only one haul per fishing trip, Madeiran vessels conduct more than two hauls per fishing trip. In fact, the duration of fishing trips in Madeiran waters has increased to five or more days in the last years, reflecting a search for more distant grounds to capture the species.

Hierarchical cluster analysis has been previously attempted in the literature to find groups of vessels with similar characteristics and/or strategies (GarcíaRodríguez, 2003; Tzanatos et al., 2004). Through cluster analysis, vessels were aggregated based on three technical characteristics: LOA, tonnage and engine power.

From the results presented, it is clear that the longline fisheries from the Portuguese EEZ exhibited similar temporal patterns regarding fishing capacity. In effect, both fisheries have shown an increase in fleet size between the late 1980s and the early 1990s followed by a decrease from the late 1990s to the early 2000s. This last reduction was closely accompanied by an investment in technology: larger vessels with higher engine power and also new equipment, such as a winch engine to haul the gear. As seen in Figure 2 , the increase in vessel dimensions and power had more expression in the mainland fishery. 
In the fishing regime, each fishery still displays a different strategy. In the Madeiran fishery, vessels conduct several hauls during fishing trips that can last up to 7 days, whereas in the mainland fishery hauls are only completed after two fishing trips (one for setting and the other for hauling). These differences most probably have economic reasons but could also be related to resource availability at the fishing grounds. For instance, the great majority of mainland fishery vessels prefer to sell fresh fish at the landing market than to invest in freezing facilities onboard. On the other hand, from the information collected in interviews with skippers (Bordalo-Machado and Figueiredo, 2009), it is known that vessels almost exclusively target the same fishing ground throughout the year, but landings per vessel only occur three times a week. It therefore appears that they cannot obtain higher hauling yields every day at the same ground on the Portuguese continental slope.

Madeiran vessels conducted fishing trips of more than one day long before the 1980s. Vessels tend to target more than one ground on the same fishing trip, but the seafloor topography around Madeira is different from that on the mainland slope. Does black scabbardfish aggregate in a similar way in the two fishing regions? This question remains unanswered pending further research, to which the analysis of logbooks from both fisheries and information collected in independent research surveys can make a valuable contribution when they became available.

The discard percentages obtained during the onboard sampling programme conducted off the mainland were very low. The catches in number and in weight were almost exclusively composed of the target species Aphanopus carbo. The majority of the discarded specimens were non-commercial species, with percentages and frequencies consistently low on the sampled trips. We can almost say that this is a very "clean" fishery regarding discarded species. Onboard sampling showed the presence of almost 35 different species caught by the mainland fishery, with $66 \%$ discarded at very low levels. From the 20 different species landed, only target species numbers were significant. Results also showed that sharks compose nearly $50 \%$ of catches. Connolly and Kelly (1996) obtained similar results: sharks also dominated deep-water longline surveys.

Regarding GLM analysis of discards data, it is worth mentioning that the models presented assumed that qualitative explanatory variables were not significant. Both models (weight and number) depend only on main effects (number of hooks, soaking time and depth). This result is in accordance with those of Løkkeborg (1994) and Olsen and Laevastu (1983), who refer to the influence of these technical factors on catches, which can therefore also influence discards. In the present case, discards increased with depth, but their relationship with soaking time and number of hooks was not clear. These findings need to be clarified in the near future by taking advantage of more observations.

The selected fishing effort standardisation model revealed that the predictors with the greatest influence on LPUE variability are the week and region of fishing activity and the vessel group. In fact, depending on the fishing yields obtained during a week's activity, vessel's skippers can change to nearby fishing grounds in search of better profits. Moreover, since the species spawns only in a restricted period of the year (Figueiredo et al., 2003), it is expected that fish availability is not the same throughout the year. Regarding the vessel group, vessels with large size and fishing gear will likely obtain better fishing yields than smaller ones for the same stock size (Bordalo-Machado, 2006).

The results obtained with the comparison of the LPUE series from the two fleets were not conclusive regarding the existence of two different populations under exploitation in the Portuguese EEZ. While the non-parametric test rejected the hypothesis of the two series belonging to the same population of black scabbardfish, using LPUE time series from Madeira delayed by three months the test did not reject the hypothesis that the two series originated from the same population. Assuming that the species carries out migrations between the two regions, this result is in agreement with the following idea: repercussions of a recruitment of the species in the Madeira region only occur on the mainland after a three-month period. This means that specimens from both fishing regions may belong to the same exploited stock, a scenario that is consistent with the results of Stefanni and Knutsen (2007), who carried out a comparative phylogeography study of Aphanopus carbo using samples from four different NE Atlantic locations, including Sesimbra and Madeira waters.

In order to confirm the statistical results obtained with the time series comparison, the tests should be run using extended LPUE time series from both regions. A time series of fifteen years seems reasonable since it is quite close to the expected longevity of the species, considering that the latest scientific 
evidence indicates a maximum age of 15 years in specimens of Madeira (Vieira et al., 2009).

\section{ACKNOWLEDGEMENTS}

This work was supported by the EU-funded project APHACARBO: Black Scabbardfish in the Portuguese waters: conservation measures and fish quality control (POCTI/CVT/46851/2002) and by the EU Data Collection Regulation National Programme. We thank the colleagues who did onboard sampling, Ana Ferreira, Dina Silva, Elisabete Henriques, Paula Abreu and Susana Barbosa, and also the skippers of the longline vessels who cooperated with the discard sampling programme.

\section{REFERENCES}

Akaike, H. - 1973. Information theory and an extension of the maximum likelihood principle. In: B.N. Petrov and F. Csaki (eds.), Proceedings of the 2nd International Symposium on Information Theory, pp. 268-281. Budapest: Publishing House of the Hungarian Academy of Sciences.

Bordalo-Machado, P. - 2006. Fishing effort analysis and its potential to evaluate stock size. Rev. Fish. Sci., 14: 369-393.

Bordalo-Machado, P. and I. Figueiredo. - 2009. The fishery for black scabbardfish (Aphanopus carbo Lowe, 1839) in the Portuguese continental slope. Rev. Fish Biol. Fish., 19: 49-67.

Caiado, J., N. Crato and D. Peña. - 2008. Comparison of time series with unequal length. Munich Pers. Res. Pap. Economics (RePEc) Arch., 6605: 1-18.

Connolly, P.L. and C.J. Kelly. - 1996. Catch and discards from experimental trawl and long line fishing in the Rockall Trough. $J$. Fish Biol., 49(Suppl. A): 132-144.

Figueiredo, I., P. Bordalo-Machado, S. Reis, D. Sena-Carvalho, T. Blasdale, A. Newton and L.S. Gordo. - 2003. Observations on the reproductive cycle of the black scabbardfish (Aphanopus carbo Lowe, 1839) in the NE Atlantic. ICES J. Mar. Sci., 60(4): 774-779.

Fitch, J.E. and D.W. Gotshall. - 1972. First record of the black scabbard fish, Aphanopus carbo, from the Pacific Ocean with notes on other California Trichiurid fishes. Bull. South Calif. Acad. Sci., 711: 12-18.

García-Rodríguez, M. - 2003. Characterisation and standardisation of a red shrimp, Aristeus antennatus (Risso, 1816), off the Alicante gulf (SE Spain). Sci. Mar., 67(1): 63-74.

Haldiki, M., Y. Batistakis and M. Vazirgiannis. - 2002. Cluster validity methods, SIGMOD, Record, 31: 40-45.

Hastie, T.J. and D. Pregibon. - 1992. Generalized linear models. In: J.M. Chambers and T.J. Hastie (eds.), Chapter 6 of Statistical Models in $S$, Wadsworth \& Brooks/Cole.

Holley, J.-F. and P. Marchal. - 2004. Fishing strategy development under changing conditions: examples from the French offshore fleet fishing in the North Atlantic. ICES J. Mar. Sci., 61(8): 1410-1431.

ICES. - 2001. Report of the working group on the biology and assessment of deep-sea fisheries resources (WGDEEP). ICES CM 2001/ACFM:23, 46 pp.
ICES. - 2006. Report of the Working Group on the Biology and Assessment of Deep-sea Fisheries Resources (WGDEEP). ICES CM 2006/ACFM:28, 504 pp.

ICES. - 2008. Report of the Working Group on the Biology and Assessment of Deep-Sea Fisheries Resources (WGDEEP). ICES CM 2008/ACFM:14, 531 pp.

Løkkeborg, S. - 1994. Fish Behaviour and Longlining. In: A. Fernö and S. Olsen (eds.), Marine fish behaviour in capture and abundance estimation, pp. 9-27. Fishing News Books. Oxford, England.

Martins, R. and C. Ferreira. - 1995. Line fishing for Black scabbardfish (Aphanopus carbo Lowe, 1839) and other deep water species in the eastern mid-Atlantic to the north of Madeira. In: A.G. Hooper (ed.), Deep-Water Fisheries of the North Atlantic Oceanic Slope, pp. 323-335. Kluwer Academic Publishers, Dordrecht.

McCullagh, P. and J.A. Nelder. - 1989. Generalized Linear Models. Chapman and Hall, London.

Merret N.R. and R.L. Haedrich. - 1997. Deep-Sea Demersal Fish and Fisheries. Chapman and Hall.

Morales-Nin B., Ã. Canha, M. Casas, I. Figuereido, L.S. Gordo, J.D.M. Gordon, E. Gouveia, C.G. Piñeiro, S. Reis, D. Reis and S.C. Swan. - 2002. Intercalibration of age readings of deepwater black scabbardfish, Aphanopus carbo (Lowe, 1839). ICES J. Mar. Sci., 59: 352-364.

Nakamura I. and N.V. Parin. - 1993. FAO species catalogue, Snake mackerels and cutlassfishes of the world (Families Gempylidae and Trichiuridae). FAO Fish. Synop., 125 (15): 1-136.

Olsen, S. and T. Laevastu. - 1983. Factors affecting catch of long lines, evaluated with a simulation model of long line fishing. North. Alaska Fish. Center Nat. Mar. Serv. U.S Dep. Commerce.

Pajuelo, J.G., J.A. González, J.I. Santana, J.M. Lorenzo, A. García-Mederos and V. Tuset. - 2008. Biological parameters of the bathyal fish black scabbardfish (Aphanopus carbo Lowe, 1839) off the Canary Islands, Central-east Atlantic. Fish. Res., 92: 140-147.

Parin, N.V. - 1986. Trichiuridae. In: P.J. Whitehead, M.L. Bauchot, J.C. Hureau, J. Nielsen and E. Tortonese (eds.), Fishes of the North-east Atlantic and the Mediterranean, vol. 2, pp. 976-980. UNESCO, Paris.

R Development Core Team. - 2006. $R$ - a language and environment for statistical computing. R Foundation for statistical computing, Vienna, Austria, ISBN 3-900051-07-0, URL http:// www.R-project.org.

Reis, S., D. Sena-Carvalho, J.H. Delgado and M. Afonso-Dias. 2001. Historical Overview of the Black Scabbardfish (Aphanopus carbo Lowe, 1839) Fishery in Madeira Island. Deep-Sea Fish. Symp., NAFO SCR Doc. 01/103, 6 pp.

Santos, A.M.P. - 2000. Environment and biology of deep-water species Aphanopus carbo in NE Atlantic: basis for its management (BASBLACK). Final Consolidated Rep. Eur. Comm. DGXIV Study Contract, 97/0084, 94 pp.

Stefanni, S. and H. Knutsen. - 2007. Phylogeography and demographic history of the deep-sea fish Aphanopus carbo (Lowe, 1839) in the NE Atlantic: Vicariance followed by secondary contact or speciation? Mol. Phylog. Evol., 42: 38-46.

Tzanatos, E., E. Dimitrioub, G. Katselisc, M. Georgiadisa and C. Koutsikopoulosa. - 2004. Composition, temporal dynamics and regional characteristics of small-scale fisheries in Greece. Fish. Res., 73:147-158.

Vieira, A.R., I. Figueiredo, I. Farias, A. Neves, B. Morales-Nin, V. Sequeira and L.S. Gordo. - 2009. Age and growth of black scabbardfish (Aphanopus carbo Lowe, 1839): bias and precision of ageing methods and age readers. Sci. Mar., 73S2: 33-46.

Wood, S.N. -2006. Generalized additive models. An introduction with $R$. Chapman and Hall/CRC.

Scient. ed.: P. Martín

Received December 12, 2008. Accepted October 2, 2009.

Published online December 22, 2009. 